\title{
A Conceptual Model for Evaluating Impact of the Local Search Engine Projects (LOSEPs) on Sustainable Development based on Sustainability Indicators
}

\author{
Mohammad Azadnia \\ Faculty Member and Head of \\ Information Technology \\ Laboratory, ICT Research \\ Center
}

\author{
Shamsossadat Zahedi \\ Faculty Member and Professor \\ of Allameh Tabatabae \\ University
}

\author{
Alireza Yari \\ Faculty Member and Head of \\ Information Technology \\ Faculty, ICT Research Center
}

\begin{abstract}
This paper first provides an introduction to sustainable development and indicators of sustainability. Then, the Local Search Engine (LSE), its achievements and projects will be discussed. The accomplishment of Local Search Engine Projects (LOSEPs) involves a set of micro- and macro-scale projects [Appendix 1].
\end{abstract}

Sustainable development concentrates on inter- and intragenerational justice, and exploitation of resources in a way to preserve and improve the natural environment for present and future generations. Sustainable development primarily highlights the environment and subsequently the economy, community, politics and other areas.

By developing a set of tools, LOSEPs intends to provide a variety of services, attract more users and influence their lives. Through interaction with users inside the cyberspace, LOSEPs serves to earn huge revenues while setting the ground for transforming lifestyles. The search engine services require several stages, including web crawling, data collection, classification and indexing, storage, retrieval, and so on.

This paper investigated the effects of Local Search Engine Project (LOSEPs) implemented on various aspects of sustainable development. These effects were measured based on indicators of sustainability proposed at international institutions. The expert opinions in this field were obtained through interviews and a questionnaire to determine the efficacies. Finally, the conceptual model was proposed for the effects of LOSEPs on sustainable development and its dimensions.

\section{General Terms}

Search Engine, Sustainable Development, Indicators, Society, Economy, Environment

\section{Keywords}

Conceptual model, Effects, Local Search Engine Projects (LOSEPs), Sustainable Development

\section{INTRODUCTION}

Economic, social and human development combined with environmental development provides a new paradigm in development. Such development stresses the intergenerational and intera-generational equity and social justice, where environmental protection is a fundamental pillar. Known as sustainability and sustainable development, this new paradigm involves various dimensions, the most important of which are environmental, economic and social [1].
Meeting its final months of implementation, the first phase of LOSEPs includes several projects focusing on search. Under the framework of LOSEPs, several projects are being completed or planned, such as search engine for text, image, map, email, browser, translation system, basic tools of Persian language development and many other projects. A more comprehensive list of LOSEPs projects has been given in Table (2), which is also available on LOSEPs's website [2].

This study sought to examine a model or method to demonstrate how and to what extent the implementation of LOSEPs can affect sustainable development. Moreover, several indicators were evaluated and a preliminary conceptual model was provided.

In this paper, the concept of sustainable development was briefly introduced and discussed. Then, the dimensions and components of sustainable development were explored, and the achievement of goals and ideals pursued by sustainable development was assessed. At the next stage, these indicators were categorized according to the main dimensions of sustainable development, including economy, community and environment as summarized in a table. Afterwards, LOSEPs and its items and stakeholders were described. Then, all the achievements of LOSEPs and their relationships with the main dimensions of sustainable development were displayed in a table. And finally, a conceptual model for the efficacy of LOSEPs on the dimensions of sustainable development was outlined as a primary tool for assessing the effects of the project on sustainable development. The last section briefly provides the conclusions and recommendations for future research.

\section{MATERIALS AND METHODS}

\subsection{Sustainable development}

Development is a process in which cultural, social, economic and political institutions transform fundamentally proportionate to the new known capacities. Throughout the process of development, the society's welfare improves. Undoubtedly, any improvement in the indicators and quality of life can be viewed as the ultimate goal of every economic and social development program.

The concept of sustainable development was first proposed by the United Nations. At a UN summit in 1972, great concentration was on the fundamental human right to freedom, equality and adequate conditions of life in a healthy environment allowing a dignified and prosperous lifestyle.

There are numerous definitions of sustainable development, some of which include: 
Sustainable development refers to the integration of economic, social and environmental goals to maximize the present human welfare without damaging the ability of future generations to meet their needs.

The World Commission on Environment and Development first presented the term, defining it as a development that fulfills the needs of the current generation without hindering the ability of future generations to meet their own needs [3].

Sustainable development involves several dimensions, the most important of which are listed below.

\subsubsection{Sustainable development from the environmental perspective}

Endangered species, destruction of forests and pollution of air and water, quantity or amount of energy consumed and the use of hazardous substances are the aspects concerning environmental sustainable development. A system of environmental sustainability should support vital sources, while preventing any indiscriminate exploitation of nonrenewable sources as well as functions leading to environmental degradation

\subsubsection{Sustainable development from the economic perspective}

Economic aspects differ from financial aspects. The latter is associated with positive financial balance sheets and the ability of an organization to fulfill human or environmental needs, whereas the economic aspect is beyond balance sheets. It rather covers global poverty, impact of economy on trade, investment and distribution of wealth, gross national product and gross domestic product. A sustainable economic system is supposed to produce goods and services, preventing any imbalance in various sectors of the economy and avoiding any damage to agricultural and industrial products. The economic dimension of sustainable development includes growth and other economic parameters, maximizing the individual and community well-being through optimal and efficient use of natural resources and equitable distribution of benefits. Sustainability in economy can be defined as creating a balanced and equitable growth of human society, while ensuring every single individual is benefited over time without causing any harm to biological, natural and cultural sources.

This dimension of sustainable development, explores the economy governing the society. The resources and technologies adopted in production activities should be coordinated with the concept of sustainable development and remain environmentally friendly. The economic structure today suffers from numerous shortcomings prior to achieving sustainability. The current economy faces, for example, poor reliance of economic factors on value principles to generate and consume wealth, low efficiency of the current economic system, dissipation of non-renewable sources, waste production, etc., no environmental and social measures to correctly price products, unbalanced and unfair economic structure and inequality between developing and developed countries, and exploitation of natural reserves instead of their surplus [1]

\section{- Sustainable development from the social perspective}

The social dimension revolves around humans and human rights. In fact, social sustainable development involves equal public access to education and health, while preventing any human exploitation and abuse. A sustainable social system needs to attain equal distribution of social facilities such as health, education, gender equalities, political accountability and participation.

In another viewpoint, sustainable development is a multifaceted concept involving various dimensions with interactive and two-way communication. It includes spiritual development, human development, social development, cultural development, political development and economic development. Energy sources, natural resources and vital sources constitute the environmental sustainable development. Social capital (including institutionalization and social cohesion) and social dynamics are considered as two social components of sustainable development. The economic components of sustainable development include labor, capital, technology and information, which underlie GDP and GNP [4].

\subsection{Formulation of a framework for sustainable development}

According to the above definitions, the environment, dimensions and objectives of sustainable development involve a process where the economic, social and environmental goals are integrated wherever possible through enforcement of policies, essential measures and support. In other cases, where integration is impossible, sustainable development builds and coordinates interconnections. Under this definition, there are three objectives (economic, social and environmental) based on which three main environments and three dimensions are as follows:

\section{Economic, social and natural environments}

2. Economic, social and environmental dimensions

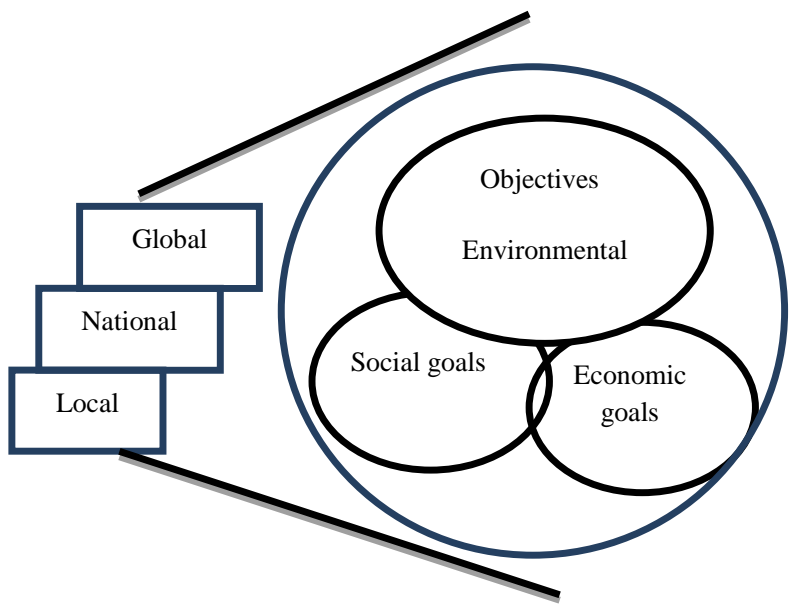

Fig 1: Sustainable development depicted by Organization for Economic Cooperation Development (OECD)

For this reason, the relevant literature has often outlined sustainable development based on those three categories. For instance, the Organization for Economic Cooperation and Development (OECD) has illustrated the objectives of sustainable development in Figure (1) [3].

However, a balanced integration of economic, social and environmental objectives requires a longer-term vision, evaluation of how current decisions will influence future generations, enforcement of laws, regulations, local emergency cooperation at national, regional and global scales, signing contracts and joining treaties, conventions and protocols and finally institutional and managerial arrangements. This in turn clarifies the environment and the next main dimension, i.e. political environment and political dimension. For this reason, four environments and four 
dimensions were outlined for sustainable development in this paper. Furthermore, governance and support structures should be achieved and established basically through setting specific political objectives. Perhaps that is why the above factors are recognized today in the sustainable development debate. Good governance requires cooperation by the public sector (government agencies), private sector and civil institutions in line with national development.

In addition, the ability to reach consensus on how to lift challenges depends on several factors such as security, institutional arrangements, participatory structures, distribution of powers and responsibilities, and setting an appropriate scope of powers and responsibilities. Therefore, the achievement of sustainable development comes with an implicit task to transform planning, implementation of sustainable development, realization of good governance and how a country is administered. Figure (2) illustrates the major goals, dimensions and environments for sustainable development based on the findings of this research. The economic dimension concerns growth and other economic parameters, where the individual and community well-being should be maximized through optimal and efficient use of natural resources and equitable distribution of benefits. The social dimension concerns the human relationships, excellence of individual well-being, health and educational services, promotion of different cultures, equality and the eradication of poverty. The environmental dimension concerns the protection and reinforcing of physical, biological and ecosystems resources as well as the human-nature relationship. The political dimension deals with the law, policy-making, planning, budgeting, institutionalization and social environment. It revolves around diversity and pluralism, respect for human rights and effective public participation in decision-making. It also adjusts the conditions for the integration of several goals by creating an interconnection for attaining sustainable development [3].

\subsection{Indicators of sustainable development}

Parallel to the evolution of the sustainable development paradigm, followed by definition and identification of indicators of sustainable development, there are various methods to assess the indicators of sustainable development. Such variety arises from different attitudes toward sustainable development. Economic scholars often assess sustainability through economic and monetary indicators, while environmental experts and ecologists have frequently adopted physical and biological indicators for assessment of sustainability. Between the above two categories, there are experts and thinkers who strive to adopt a set of such indicators for assessment of sustainability. The common denominator of these methods, however, is to instigate public opinion, policy- and decision-makers, in an effort to establish a balance between various dimensions of sustainable development [5].

In order to better understand the sustainability assessment methods, this paper analytically examined several indicators, including Human Development Index (HDI), Ecological Footprint (EF), Surplus Bio-capacity (SB), Genuine Savings (GS) and Environmental Vulnerability Index (EVI). In addition to the above indicators, Gross Domestic Production (GDP) was explored owing to its link to various aspects of sustainable development [9].

\subsubsection{Ecological Footprint (EF)}

$\mathrm{EF}$ is adopted to measure resource consumption and pollutant absorption for a specific population or economy. This concept has become the subject of comparing sustainability levels in different countries. In fact, EF compares the effects and consequences of communities, regions, countries and individuals on the environment by converting them into lands required for production of basic needs and absorption of pollutants. In other words, EF links human lifestyle to environmental consequences [6], [7].

\subsubsection{Surplus Bio-capacity (SB)}

Similar to Ecological Footprint, SB assesses the sustainability of consumption patterns. This indicator is calculated by subtracting EF from arid and low-fertility land areas. The SB level depends on the fertile ecological spaces, consumption and population [6].

\subsubsection{Genuine Savings (GS)}

GS represents the net value of change in total assets of a country essential for national development (e.g. produced assets, natural resources, human capital and foreign assets).

In fact, GS portrays the country's wealth within a framework different from national accounts [8].

\subsubsection{Environmental Vulnerability Index (EVI)}

EVI represents the extent of the risks threatening the natural environment. In 1998, the UN Commission on Sustainable Development (CSD) initiated efforts to devise environmental vulnerability factors in collaboration with South Pacific Applied Geoscience Commission. EVI is a numerical dimensionless indicator depicting the vulnerability of the environment in a country.

\subsubsection{Gross Domestic Production (GDP)}

GDP refers to the total value of all goods and services produced within a country's borders, particularly for a given period of time usually one year. In order to better evaluate and analyze the relationship between the indicators, GDP is also adopted because of its importance in sustainable development issues, particularly in terms of sustainable economic development.

\subsubsection{Human Development Index (HDI)}

HDI represents life expectancy at birth, access to education and acceptable standard of living.

In fact, HDI is the most prominent instance of modern viewpoints coupled with the development of assessment tools for international comparisons in the field of development.

Based on three main components of life, HDI is composed of three aspects as follows:

\section{- Life expectancy at birth}

- Access to education

- Acceptable standard of living [9].

\subsubsection{Environmental Sustainability Index (ESI)}

ESI assesses the capabilities of nations to protect the environment over the next few decades. It covers environmental systems, reduction of environmental pressures, reduction of human vulnerability to environmental pressures, social and corporate capacity for accountability to environmental challenges and global monitoring.

\subsubsection{Environmental Performance Index (EPI)}

EPI highlights the dimensions of environmental sustainability, assessing the quality of national policies and plans concerning the reduction of environmental issues and conservation of the environment and natural resources [5]. 


\subsection{Classification of indicators and development of the assessment model}

After reviewing the ICT and sustainable development models, we intended to devise a new model covering several indicators for assessing the effects of ICT on sustainable development. The dimensions of sustainable development can be assessed from three perspectives: economic, social and environmental. Section 2-3 enumerated eight indicators to measure sustainable development. Depending on their natures, these indicators can be mapped into economic, social or environmental dimensions. Table 1 displays the main dimensions of sustainable development in sustainability assessment methods mapped into triple components. As seen in the table, a few of these indicators fall in two dimensions based on their characteristics. For example, GS involves both environmental and economic characteristics.

Table 1. Dimensions and indicators of sustainable development

\begin{tabular}{|c|c|c|c|c|c|c|c|c|c|c|}
\hline \multicolumn{11}{|c|}{ Sustainable development } \\
\hline Dimensions & Soc & & & & Eco & mic & En & nme & & \\
\hline 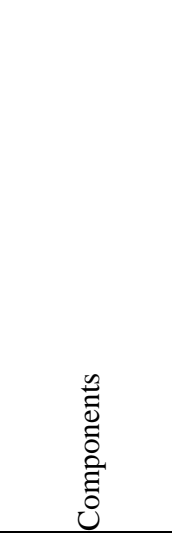 & 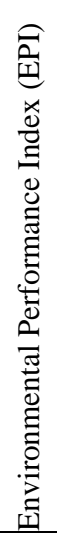 & 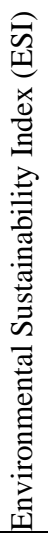 & 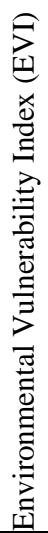 & 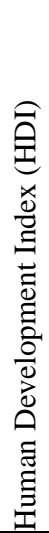 & 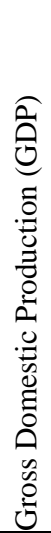 & 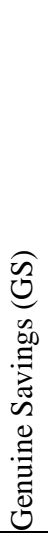 & 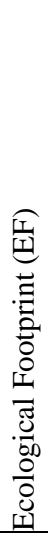 & 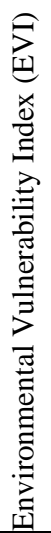 & 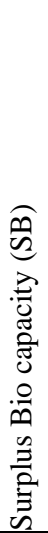 & 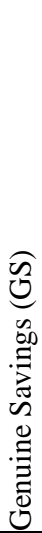 \\
\hline
\end{tabular}

\subsection{Local Search Engine Project (LOSEPs)}

LOSEPs involve a series of different projects (roughly 50) whose titles were specified during preliminary studies.

As the outcomes of project operations, the achievements of LOSEPs provide desirable indicators for analyzing the efficacy of the project on sustainable development.

\section{RESULTS AND DISCUSSIONS}

\subsection{Achievements of LOSEPs}

The first step to evaluate how and to what extent LOSEPs affects sustainable development is to evaluate its achievements. Upon completion of projects and realization of goals related to each project, the macro- and micro-scale achievements of LOSEPs, will be as follows.

-Supplying the hardware infrastructure and bandwidth at primary and backup data centers

-Expanding the infrastructure for Persian language processing and content

-Developing the basic search engine service platforms and related services

-Developing the basic search engine added-value service and related services

-Promoting the LOSEPs' business environment

\subsection{LOSEPs' items}

The items on which the LOSEPs subject is applicable come in a wide variety each offering its own specific requirements. Prior to being provided, LOSEPs' services require several steps such as data collection, storage, search, etc. which should be implemented through strategies highly dependent on the type of item and nature of the data.

As mentioned earlier, there is a broad range of items on which the subject of LOSEPs is applicable. These items can include text, image, video or animation, sound, and map, each of which covers various formats based on their applications [2]

\subsection{Characteristics of LOSEPs items}

Nowadays, traditional solutions are no longer useful because of the new nature of data. It is crucial to select a solution, product and infrastructure based on the characteristics of each item. In terms of characteristics, data are identified through seven features as follows.

Volume: Data have rapidly enlarged from terabytes to petabytes, and then to Exabyte and zettabytes. According to recent estimates, the volume of data is growing exponentially just as data are produced in various applications.

Table 2. Equivalent weight for Likert scale

\begin{tabular}{|l|l|}
\hline \multicolumn{1}{|c|}{ Level of effect } & Equivalent number \\
\hline High positive effect & 2 \\
\hline Low positive effect & 1 \\
\hline Ineffective & 0 \\
\hline Low negative effect & -1 \\
\hline High negative effect & -2 \\
\hline
\end{tabular}


Speed: Through numerous software applications and sensors embedded in the environment, data are produced at a skyrocketing rate in real time. Many applications require responding to user as soon as data are inserted. Just as data are being quickly produced, they need to be processed at higher rates. Any delay in data processing decisions will lead to loss of opportunities.

Diversity: Big data are extremely diverse in terms of format, type and structure. For instance, textual, numeric, graphic, audio, video, sequential, time series and social media data (e.g. Facebook) and multi-dimensional vectors can be found in big data.

Accuracy: Since data are received from various sources, they may all not be trustworthy. Accuracy refers to retaining every single characteristic of original data, so as to ensure the quality and integrity of big data.

Authenticity: Assuming that data are correct, they may not be suitable for certain applications, i.e. they may not be sufficiently authentic for a few applications.

Fluctuation: This concern the trade policy adopted for information protection. Due to information fluctuations, protection of sales information may not be necessary for more than one year in a simple e-commerce application. In case of big data, however, it is critical to protect data for long periods.

Value: This implies whether or not the costs of data maintenance and processing worth it in commercial and decision-making terms. Normally, data can be moved at different levels. Upper layers represent greater value of data.

\subsection{LOSEPs' stakeholders}

The stakeholders can generally be classified into two groups of clients and contributors. The clients of LOSEPs services are actually consumers classified into two natural and legal entities. Natural stakeholders are the end users of services, while legal stakeholders include organizations and companies consuming content.

\subsection{Requirements of LOSEPs' stakeholders}

According to surveys on popular websites and information gained about attractive, widely-demanded services among

Table 2. Efficacy weight of LOSEPs' major achievements on the dimensions of sustainable development

\begin{tabular}{|l|l|l|l|l|}
\hline \multicolumn{1}{|l}{} & Major Achievement & & \\
\hline 1 & $\begin{array}{l}\text { Supplying the hardware infrastructure and bandwidth at primary and backup } \\
\text { data centers }\end{array}$ & -1.1 & 1.2 & 1.1 \\
\hline 2 & Expanding the infrastructure for Persian language processing and content & 0.21 & 1.26 & 0.99 \\
\hline 3 & Developing the basic search engine service platforms and related services & 0.22 & 1.4 & 1.3 \\
\hline 4 & Developing the basic search engine added-value service and related services & 0.3 & 1.41 & 1.33 \\
\hline 5 & Promoting the search engine's business environment & 0.36 & 1.28 & 1.5 \\
\hline & Average Efficacy & 0.27 & 1.31 & 1.24 \\
\hline
\end{tabular}

The results in table 3 were applied to figure 2 and the effects of the achievements on the dimensions of sustainable development were considered directly by eliminating the intermediate indicators in figure 4.
Iranian users, the user required data were classified into two categories of content and information.

\subsection{Effects of LOSEPs' categories contributing to pre-specified dimensions of sustainable development}

After specifying the indicators of sustainability and development in LOSEPs, a questionnaire was constructed with 40 items concerning the efficacy of each achievement on the eight indicators of sustainability. The questionnaire was then sent to 47 experts in the two areas. A total of 36 questionnaires was returned completely and correctly. A fivepoint Likert scale was used in the questionnaire showed in table (2).

The results of inventory data mining were extended from indicators of sustainability to dimensions of sustainability according to Table (1) and Figure (3). Table (4) summarizes the results.

\subsection{Assessment model for the effects of LOSEPs on sustainable development}

The indicators of development were put together to easily map them out and extract the assessment model for the efficacy of LOSEPs' achievements and sustainable development. Table 3 puts together LOSEPs' achievements and indicators of sustainable development.

Figure (3) illustrates the conceptual model for LOSEPs' impacts on sustainable development. In this figure, there are five dimensions contributing to the efficacy of the LOSEPs including hardware infrastructure, processing infrastructure, development of service platforms, development of electronic services, and business development. The figure covers the effects of all eight indicators of sustainable development, including human development, environmental performance, environmental sustainability, environmental vulnerability, ecological footprint, surplus bio-capacity, genuine savings and gross domestic product.
The impact of five major achievements of LOSEPs on different dimensions of sustainable development is being compared in fig 2 . 


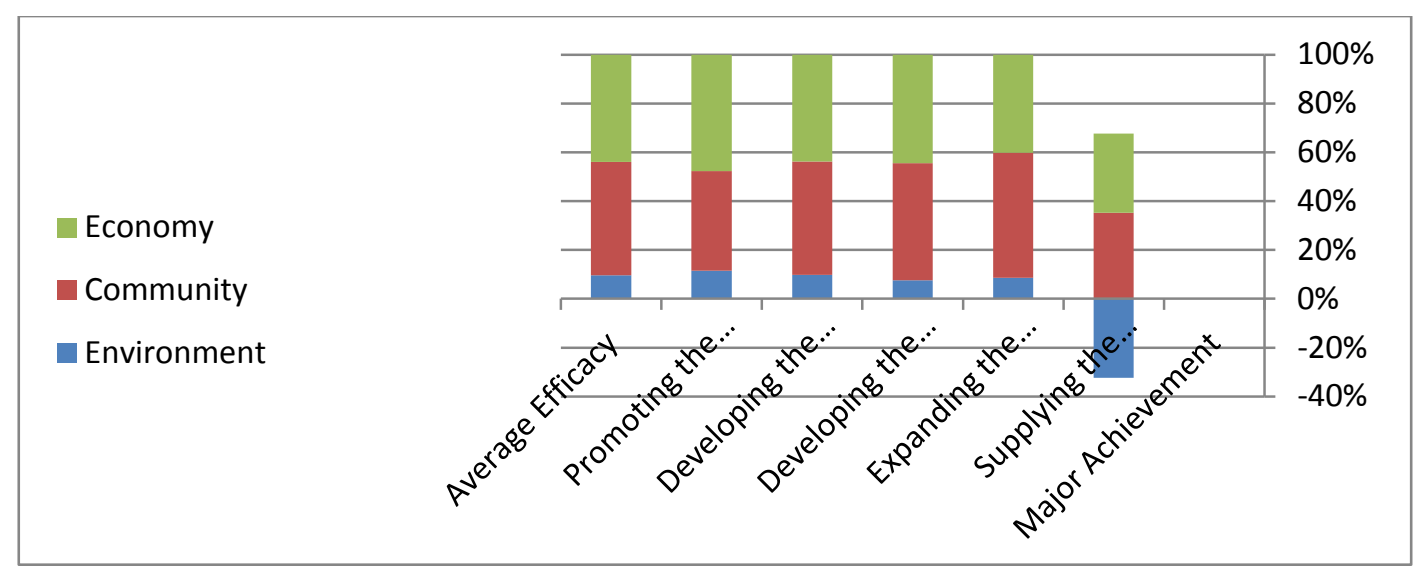

Fig 2: Efficacy weight of LOSEPs' major achievements on the dimensions of sustainable development

\section{CONCLUSIONS}

In this study, the brief history and the main subjects of sustainable development were discussed. At the next stage, a definition of sustainability was provided and the principles of sustainable development and key challenges were discussed. Moreover, the definitions, approaches and models of sustainable development were described. Then, the framework of sustainable development, environments, dimensions and objectives were specified and the conceptual model was proposed. Environmental scientists and enthusiasts believe that sustainable development is inevitable for improving the lives of the present generation and future generations. In another part of this study, the goals and ideals of sustainable development were discussed based on a global consensus to replace them with goals and ideals of the millennium. Then, the current trend was examined based on the renewed political commitment of countries and the green economy approach. As LOSEPs is implemented, facilities and tools will be provided to accelerate the attainment of objectives in sustainable development. The results of the above table suggested that the achievements of LOSEPs positively affected the various dimensions of sustainable development, thus improving its indicators. However, the efficacy of each achievement varied in different dimensions of sustainable development. In other words, the greatest effect was left on the social dimension at $1.31(65.5 \%)$ followed by economic dimension at $1.24(62 \%)$. Compared against the maximum level, the efficacy on the environment was insignificant at $0.27(13.5 \%)$. Finally, a model was proposed for explaining the efficacy of LOSEPs on sustainable development.

\section{FUTURE STUDIES}

Considering it is possible to have more indicators in the sustainable development and LOSEPs areas, inclusion of more detailed indicators in the analysis can lead to more accurate results. Therefore, it is suggested that this research be done with more detailed indicators and other dimensions of these two domains.

This research has been done using qualitative and quantitative methods with the data obtained from the questionnaire. It is suggested that this research be repeated with the use of experimental data to have more accurate result. 


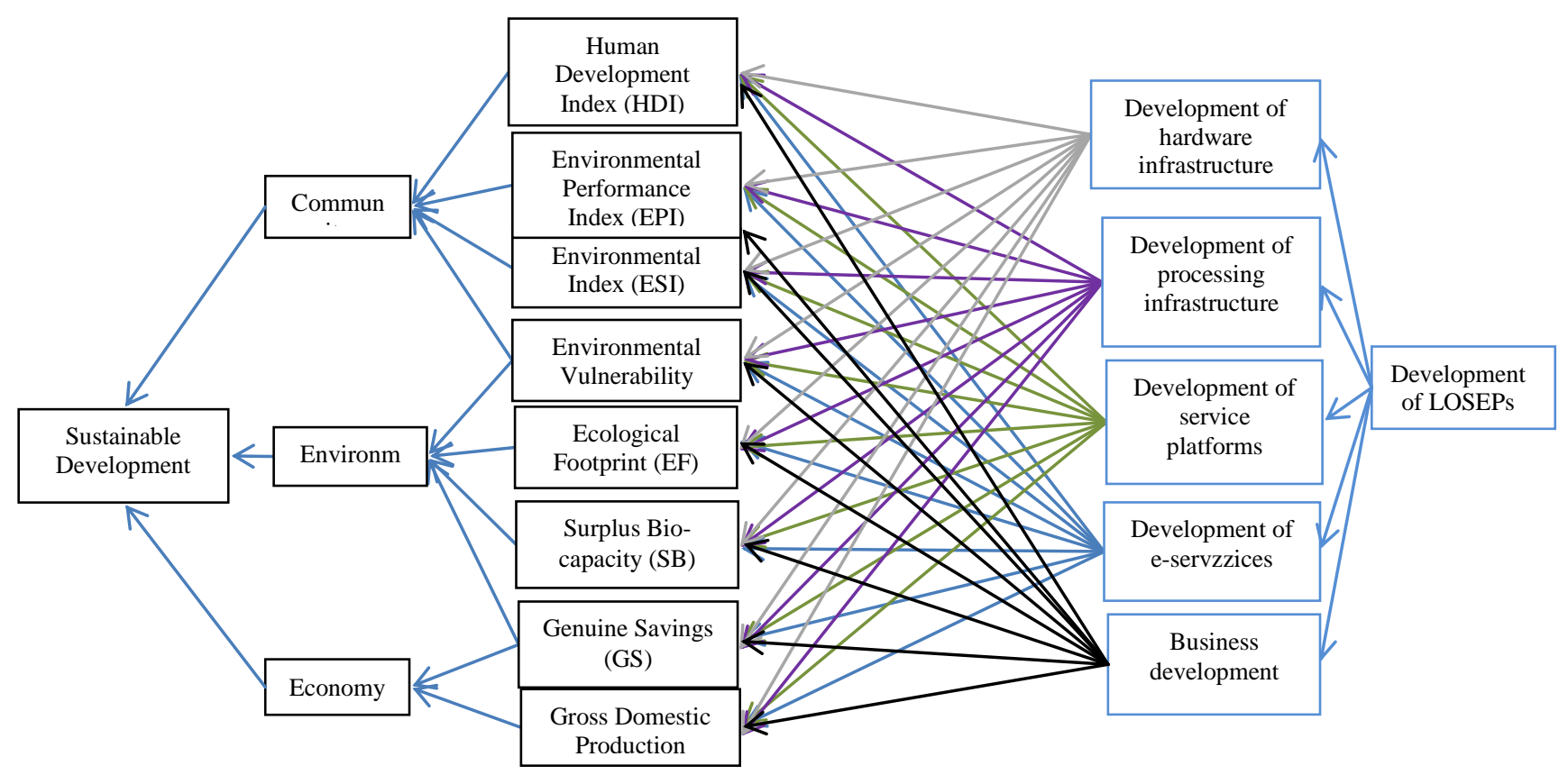

Fig 3: The conceptual model for efficacy of LOSEPs on indicators of sustainability

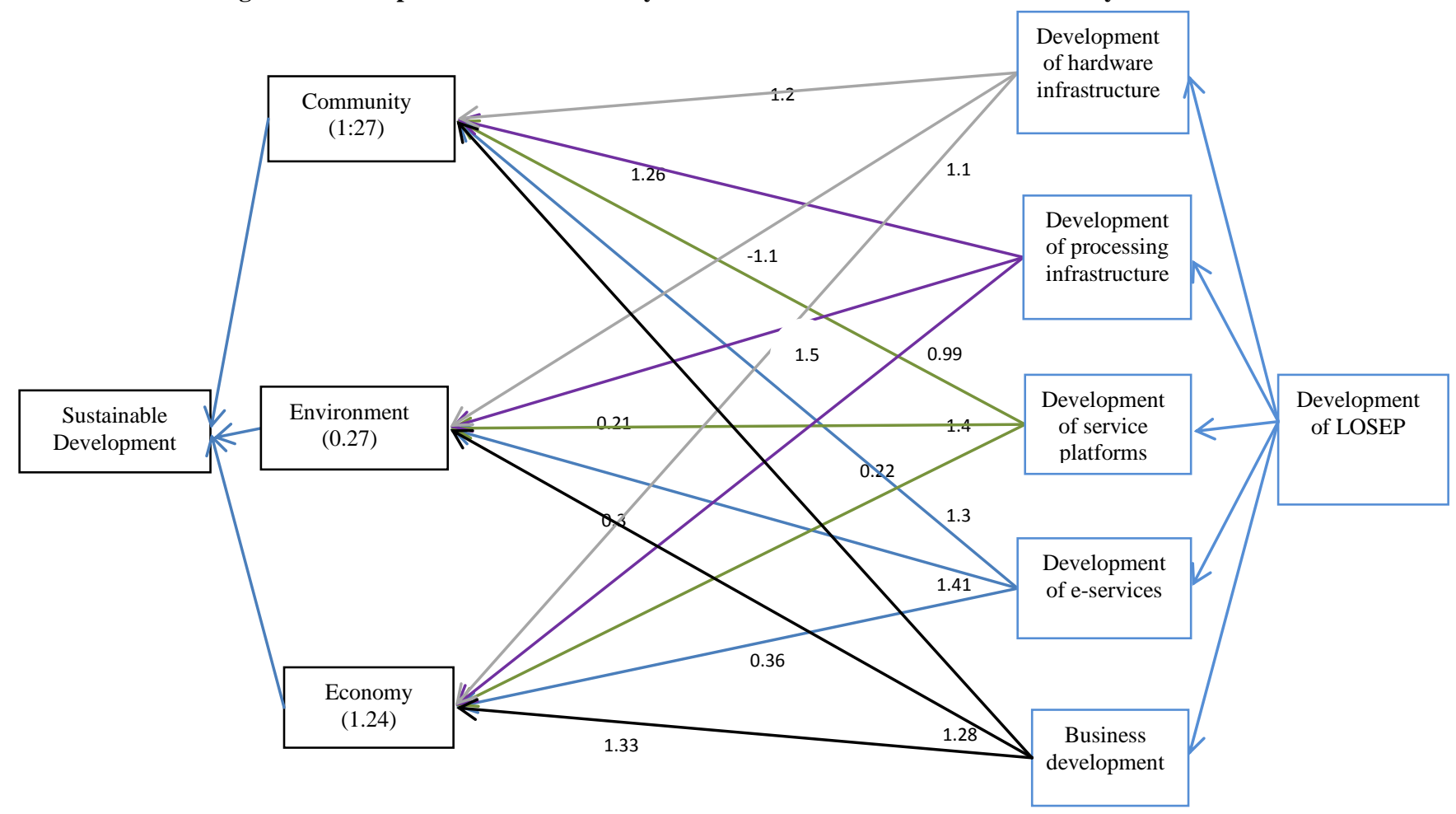

Fig 4: Conceptual model for efficacy of LOSEPs on indicators of sustainability

\section{ACKNOWLEDGEMENT}

Foremost, I would like to express my sincere gratitude to my supervisor Prof. Shamsossadat Zahedi for her continuous support of this research, for her patience, motivation, enthusiasm, and immense knowledge. Her guidance helped me in all the time of research and writing of this research.

\section{REFERENCES}

[1] Zahedi Sh. Sustainable Development. 1st ed. Tehran: SAMT; 2012. $225 \mathrm{p}$.
[2] Local Search Engine Project (LOSEPs). Available from www.didras.ir.

[3] Zahedi Sh. Comprehensive Sustainable Development with an emphasis on management and green entrepreneurship. 1st ed. Tehran: Allameh Tabatabaei University; 2016. 240 p.

[4] Javaherian Z. FatehVahdati SA. Rahmati AR. Zamani L. Objectives of Sustainable Development. Tehran: Hak Publications; 2016. 168 p.

[5] Pourasghar Sangachin F., Salehi I., Masnavi M.R. Comparative-analytical study of the methods in 
sustainable development measurement. Quarterly Environmental Researches. 2000 March; 1(1): 67-82.

[6] Harris, F. Global Environmental Issues. England: John Wiley \& Sons Ltd; 2004. 337 p.

[7] Meadows D.H., Meadows D.L., Randers J., Behrens W.W. The limits to growth. 5th ed. NY: Universe Books; 1972. $201 \mathrm{p}$.
[8] Hamilton K. Genuine Saving as a Sustainability Indicator: toward environmentally and socially sustainable development. WA: Environment Department the World Bank. 2000.

[9] United Nations Development Programs (US). Human Development Report: Millennium development goals: A compact among nations to end human poverty. NY: Oxford University Press; 2003. 375 p. ISBN 0-19521915-5.

\section{Appendix 1: Major achievements, minor achievements and measures taken by LOSEP}

\begin{tabular}{|c|c|c|c|}
\hline$\dot{8}$ & $\begin{array}{l}\text { Major } \\
\text { achievements }\end{array}$ & Minor achievements & Actions/ projects \\
\hline 1. & $\begin{array}{l}\text { 1. Supplying the } \\
\text { hardware } \\
\text { infrastructure and } \\
\text { bandwidth at } \\
\text { primary and backup } \\
\text { data centers }\end{array}$ & $\begin{array}{l}\text { Supplying the hardware infrastructure } \\
\text { and bandwidth at primary and backup } \\
\text { data centers }\end{array}$ & $\begin{array}{l}\text { Supplying the hardware infrastructure and } \\
\text { bandwidth at primary and backup data centers }\end{array}$ \\
\hline 2. & \multirow{19}{*}{$\begin{array}{l}\text { 2. Expanding the } \\
\text { infrastructure for } \\
\text { Persian language } \\
\text { processing and } \\
\text { content }\end{array}$} & $\begin{array}{l}\text { Supplying the cloud infrastructure in } \\
\text { the primary and backup data centers }\end{array}$ & $\begin{array}{l}\text { Developing the cloud infrastructure in the } \\
\text { primary and backup data centers }\end{array}$ \\
\hline 3. & & $\begin{array}{l}\text { Tools and data needed to process } \\
\text { Persian texts }\end{array}$ & $\begin{array}{l}\text { Development of the Persian-language tools and } \\
\text { data }\end{array}$ \\
\hline 4. & & Knowledge graph for Persian & Creating a knowledge graph for language \\
\hline 5. & & $\begin{array}{l}\text { Development of the Persian speech } \\
\text { processing tools }\end{array}$ & $\begin{array}{l}\text { Development of the Persian speech processing } \\
\text { tools }\end{array}$ \\
\hline 6. & & $\begin{array}{l}\text { Development of the Optical Character } \\
\text { Reader (OCR) tools }\end{array}$ & $\begin{array}{l}\text { Development of Optical Character Reader (OCR) } \\
\text { tools }\end{array}$ \\
\hline \multirow{7}{*}{7.} & & \multirow{7}{*}{$\begin{array}{l}\text { Common local data integration and } \\
\text { updating system }\end{array}$} & $\begin{array}{l}\begin{array}{l}\text { Identifying common local data } \\
\text { advantage) }\end{array} \\
\text { (competitive }\end{array}$ \\
\hline & & & $\begin{array}{l}\begin{array}{l}\text { Collecting common local data } \\
\text { advantage) }\end{array}\end{array}$ \\
\hline & & & $\begin{array}{l}\text { Devising a model for the interaction of local } \\
\text { integrators and service providers }\end{array}$ \\
\hline & & & $\begin{array}{l}\text { Devising the strategies to encourage local } \\
\text { integrators to update data }\end{array}$ \\
\hline & & & $\begin{array}{l}\text { Preparing an ecosystem of local integrators for } \\
\text { data required by search engines }\end{array}$ \\
\hline & & & $\begin{array}{l}\text { Devising a model for constructive interaction } \\
\text { between government data service providers and } \\
\text { suppliers }\end{array}$ \\
\hline & & & Utilization of the local data for monetization \\
\hline \multirow{6}{*}{8.} & & \multirow{6}{*}{$\begin{array}{l}\text { Production and development of local } \\
\text { content }\end{array}$} & $\begin{array}{l}\text { Identification and prioritization the rich resources } \\
\text { in the world. }\end{array}$ \\
\hline & & & $\begin{array}{l}\text { Devising a strategy for localizing the world's rich } \\
\text { information resources on a priority basis }\end{array}$ \\
\hline & & & Production of local content \\
\hline & & & Identification of cultural content creators in Iran \\
\hline & & & Providing a framework for cultural content \\
\hline & & & $\begin{array}{l}\text { Production of the desirable, high-quality cultural } \\
\text { content }\end{array}$ \\
\hline 9. & & $\begin{array}{l}\text { User analysis infrastructure and tools } \\
\text { (data mining) }\end{array}$ & $\begin{array}{l}\text { Development of analysis infrastructure and tools } \\
\text { (Big Data) }\end{array}$ \\
\hline
\end{tabular}




\begin{tabular}{|c|c|c|c|}
\hline$\dot{0}$ & $\begin{array}{l}\text { Major } \\
\text { achievements }\end{array}$ & Minor achievements & Actions/ projects \\
\hline & & & Providing analytical and statistical services \\
\hline \multirow{2}{*}{10.} & & \multirow{2}{*}{$\begin{array}{l}\text { Design and development of an } \\
\text { intelligent content filtering system }\end{array}$} & $\begin{array}{l}\text { Outlining the service levels (filtering according to } \\
\text { different ages) }\end{array}$ \\
\hline & & & $\begin{array}{l}\text { Development of the services tailored to different } \\
\text { ages }\end{array}$ \\
\hline 11. & \multirow{20}{*}{$\begin{array}{l}\text { 3. Developing the } \\
\text { basic search engine } \\
\text { service platforms } \\
\text { and related services }\end{array}$} & Development of a trust platform & Development of a trust platform \\
\hline \multirow[b]{2}{*}{12.} & & \multirow{2}{*}{$\begin{array}{l}\text { Local search engine security and } \\
\text { privacy requirements model }\end{array}$} & Devising a local model for privacy protection \\
\hline & & & $\begin{array}{l}\text { Devising a model for data utilization with privacy } \\
\text { protection }\end{array}$ \\
\hline \multirow{4}{*}{13.} & & \multirow{4}{*}{$\begin{array}{l}\text { The Integration model of local } \\
\text { services }\end{array}$} & $\begin{array}{l}\text { Comparative study on single input port in other } \\
\text { countries }\end{array}$ \\
\hline & & & $\begin{array}{l}\text { Formulating a single input port model (Single } \\
\text { Sign-on) for local services }\end{array}$ \\
\hline & & & Unique input platform development \\
\hline & & & Implementation and integration of services \\
\hline 14. & & The Mobile operating system (OS) & Development of mobile operating system (OS) \\
\hline 15. & & Browser & Development of browsers \\
\hline 16. & & Development of e-wallet platform & Development of e-wallet platform \\
\hline \multirow{2}{*}{17.} & & \multirow{2}{*}{$\begin{array}{l}\text { The Infrastructure service platform } \\
\text { needed for location-based services }\end{array}$} & $\begin{array}{l}\text { Development of infrastructure required for } \\
\text { location-based services }\end{array}$ \\
\hline & & & $\begin{array}{l}\text { Developing the process of preparing and updating } \\
\text { infrastructure data for location-based services }\end{array}$ \\
\hline \multirow[b]{2}{*}{18.} & & \multirow{2}{*}{$\begin{array}{l}\text { The Laboratory of evaluation and } \\
\text { validation of Persian web services }\end{array}$} & Development of service testing and evaluation \\
\hline & & & $\begin{array}{l}\text { Identification of laboratories and research centers } \\
\text { involved in the project }\end{array}$ \\
\hline 19. & & $\begin{array}{l}\text { Development of an Image Search } \\
\text { Engine }\end{array}$ & $\begin{array}{l}\text { Development of basic services for local search } \\
\text { engine (image) }\end{array}$ \\
\hline 20. & & $\begin{array}{l}\text { Development of a video search } \\
\text { engine }\end{array}$ & $\begin{array}{l}\text { Development of basic services for local search } \\
\text { engine (video) }\end{array}$ \\
\hline 21. & & $\begin{array}{l}\text { Development of a Sound Search } \\
\text { Engine }\end{array}$ & $\begin{array}{l}\text { Development of local search engine basic } \\
\text { services (sound) }\end{array}$ \\
\hline 22. & & $\begin{array}{l}\text { Development of the monitoring and } \\
\text { rating system for Internet traffic in } \\
\text { Iran }\end{array}$ & $\begin{array}{l}\text { Development of monitoring and rating system for } \\
\text { Internet traffic in Iran }\end{array}$ \\
\hline 23. & & Development of a Text Search Engine & $\begin{array}{l}\text { Development of local search engine basic } \\
\text { services (text) }\end{array}$ \\
\hline 24. & & A Map Search Engine & $\begin{array}{l}\text { Development of local search engine basic } \\
\text { services (map) }\end{array}$ \\
\hline \multirow{3}{*}{25.} & \multirow{5}{*}{$\begin{array}{l}\text { 4. Development of } \\
\text { search engine value- } \\
\text { added services and } \\
\text { additional services }\end{array}$} & \multirow{3}{*}{$\begin{array}{l}\text { Development of a general services for } \\
\text { organizations under General Service } \\
\text { Scheme }\end{array}$} & $\begin{array}{l}\text { Investigating, extracting and prioritizing the } \\
\text { common requirements of the organizations }\end{array}$ \\
\hline & & & $\begin{array}{l}\text { Development of general high-priority services for } \\
\text { the organizations }\end{array}$ \\
\hline & & & $\begin{array}{l}\text { Devising solutions to ensure the hierarchy of } \\
\text { access to corporate information. }\end{array}$ \\
\hline 26. & & $\begin{array}{l}\text { The Content and services specific to } \\
\text { countries in the region }\end{array}$ & $\begin{array}{l}\text { Identifying content and services specific to } \\
\text { countries in the region }\end{array}$ \\
\hline 27. & & Diverse location-based services on & Development of diverse location-based services \\
\hline
\end{tabular}




\begin{tabular}{|c|c|c|c|}
\hline$\dot{0}$ & $\begin{array}{l}\text { Major } \\
\text { achievements }\end{array}$ & Minor achievements & Actions/ projects \\
\hline & & mobile and web platforms & $\begin{array}{l}\text { Maximum development of location-based } \\
\text { services on mobile platform }\end{array}$ \\
\hline 28. & & Development of local social networks & Development of local social networks \\
\hline 29. & & $\begin{array}{l}\text { Development of entertainment } \\
\text { services }\end{array}$ & Development of entertainment services \\
\hline 30. & & Development of Email & Development of Email \\
\hline 31. & & Development of machine translation & Development of machine translation \\
\hline 32. & & Development of news-based services & Development of news-based services \\
\hline 33. & & The National Archive of Web & Development of web archive \\
\hline 34. & & Encyclopedia & Development of encyclopedia \\
\hline 35. & & Files and repository sharing services & $\begin{array}{l}\text { Development of file, image, video sharing } \\
\text { services }\end{array}$ \\
\hline 36. & & Multimedia sharing service & Development of TV-based services \\
\hline 37. & & $\begin{array}{l}\text { Development of special-purpose } \\
\text { search services }\end{array}$ & $\begin{array}{l}\text { Development of special-purpose search services } \\
\text { (real estate, jobs, people, children, health, } \\
\text { tourism, etc.) }\end{array}$ \\
\hline 38. & & FAQ System & Development of FAQ Systems \\
\hline 30 & & Virtul Drino & Development of cloud-based storage \\
\hline . & & - 10. & Launching a virtual drive \\
\hline 40. & & Product search and trade services & Development of trade services \\
\hline 41. & & Smart advertising platform & Development of smart advertising platform \\
\hline & & & Development of priority services for the users \\
\hline & & & $\begin{array}{l}\text { Development of all common foreign services } \\
\text { locally }\end{array}$ \\
\hline & & & Identifying unavailable services required by users \\
\hline 42. & & Services based on new needs & $\begin{array}{l}\text { Investigating solution to reduce international } \\
\text { traffic }\end{array}$ \\
\hline & & & $\begin{array}{l}\text { Investigating, extracting and prioritizing the user } \\
\text { requirements }\end{array}$ \\
\hline & & & Full coverage of high-traffic services \\
\hline 43. & & $\begin{array}{l}\text { Linguistic rewriting of query systems } \\
\text { for Persian and local dialects }\end{array}$ & $\begin{array}{l}\text { Supporting Arabic, Kurdish, English, Turkish and } \\
\text { Pashto }\end{array}$ \\
\hline 44. & & $\begin{array}{l}\text { Development of services tailored to } \\
\text { different ages }\end{array}$ & Development of services tailored to different ages \\
\hline \multirow{3}{*}{45} & \multirow{7}{*}{$\begin{array}{l}\text { 5. Promoting the } \\
\text { search engine's } \\
\text { business } \\
\text { environment }\end{array}$} & \multirow{3}{*}{$\begin{array}{l}\text { Development of the idea of creation } \\
\text { platform and commercialization of } \\
\text { ideas under the project }\end{array}$} & $\begin{array}{l}\text { Motivational policy-making for outlining new } \\
\text { ideas }\end{array}$ \\
\hline & & & Evaluation of ideas \\
\hline & & & $\begin{array}{l}\text { Soliciting sponsors for implementation of new } \\
\text { ideas }\end{array}$ \\
\hline 46. & & Research projects & \\
\hline \multirow{3}{*}{47.} & & \multirow{3}{*}{$\begin{array}{l}\text { Development of business models for } \\
\text { LOSEP services }\end{array}$} & $\begin{array}{l}\text { Formulating policies to support the production of } \\
\text { local content }\end{array}$ \\
\hline & & & $\begin{array}{l}\text { Policies to reduce government involvement in } \\
\text { service delivery }\end{array}$ \\
\hline & & & Studying and formulating practical solutions to \\
\hline
\end{tabular}




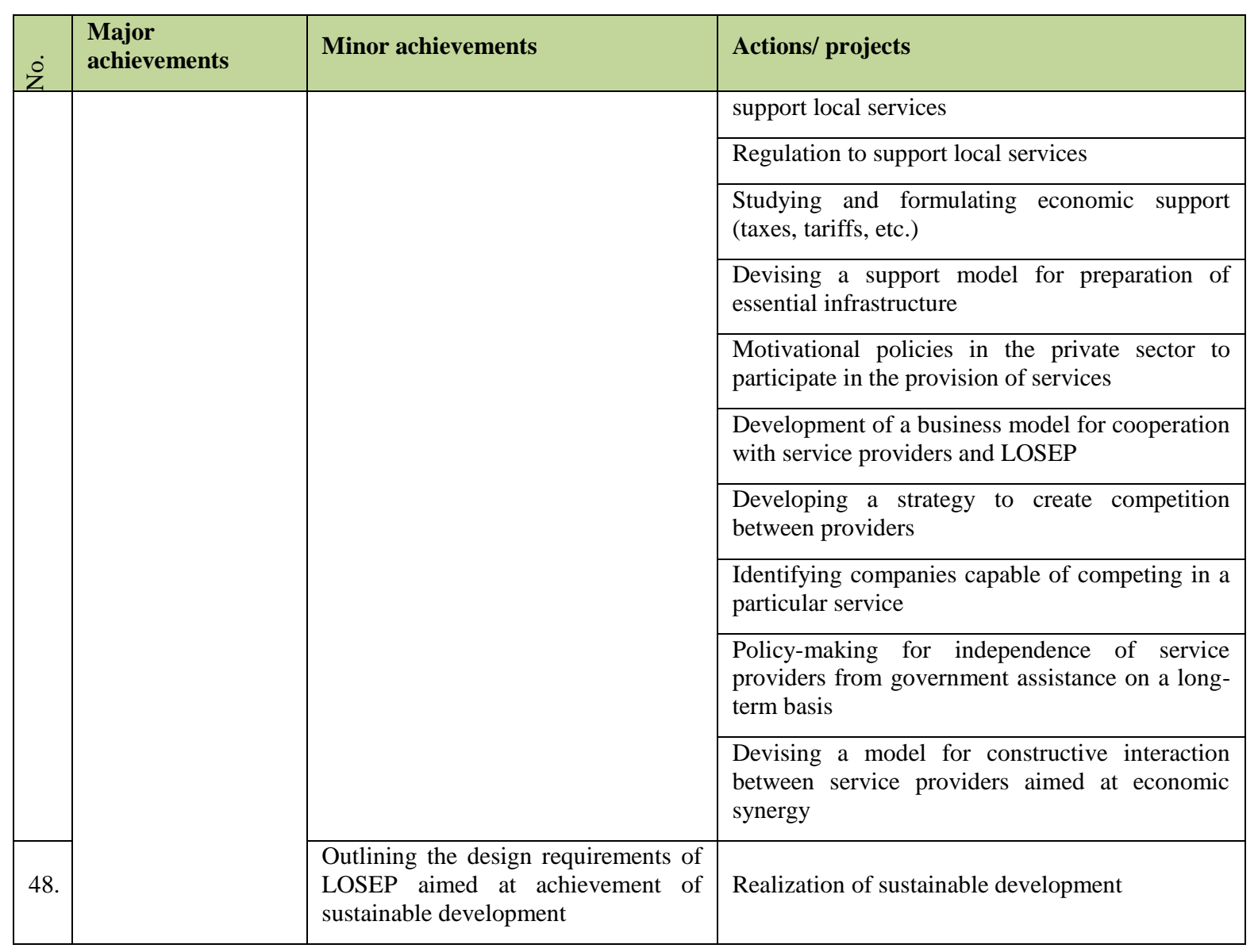

